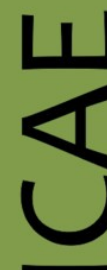

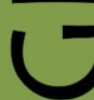

ex Instituto Archaeologico Universitatis de Rolando Eötvös nominatae

O

$\overrightarrow{0}$

山

$\leftarrow$

I

$\cup$

ه

$\leftarrow$

u

Ш

Z

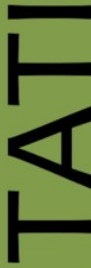

œ

ш

n

n

$\varnothing$
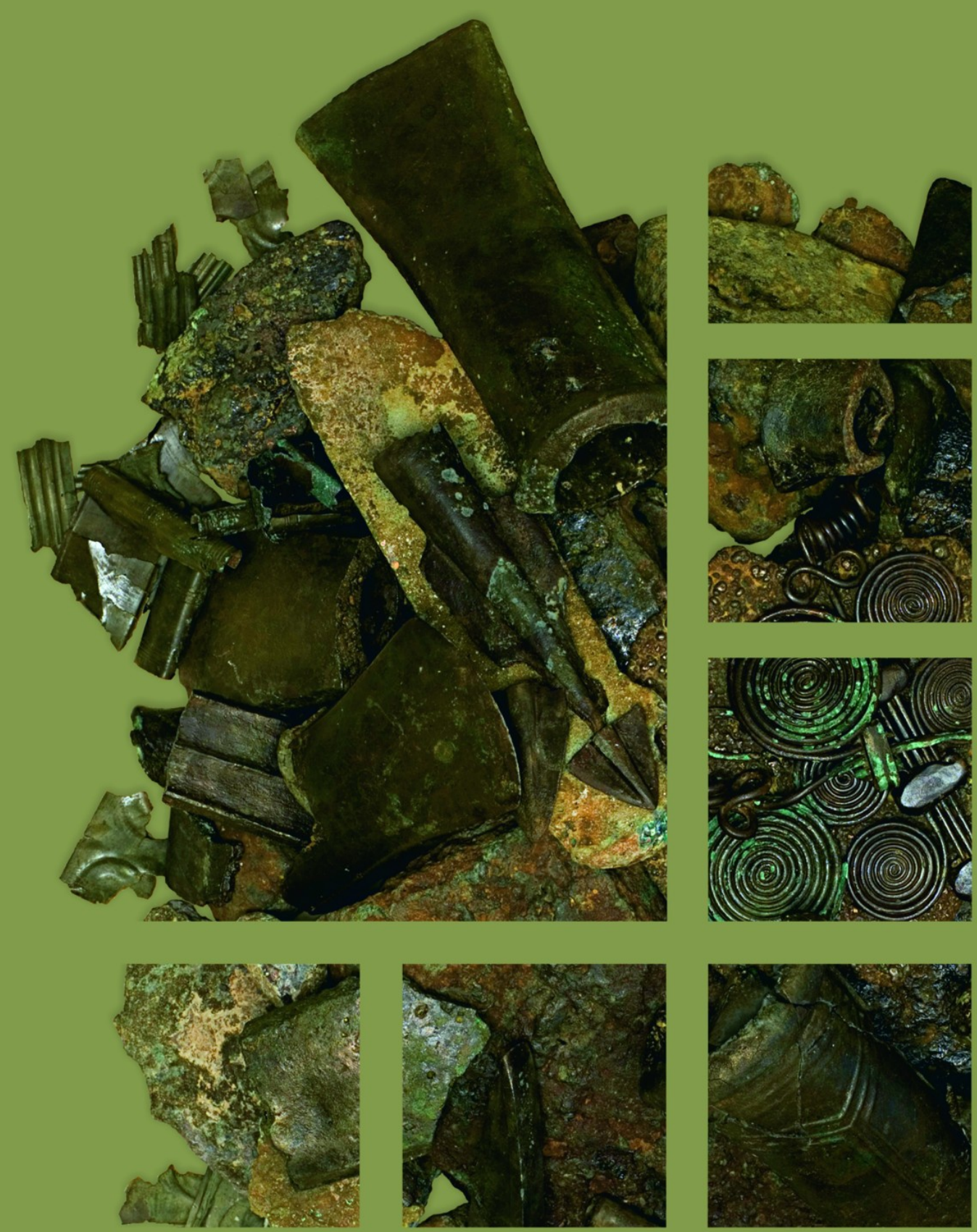


\section{Dissertationes Archaeologicae ex Instituto Archaeologico}

Universitatis de Rolando Eötvös nominatae Ser. 3. No. 2.

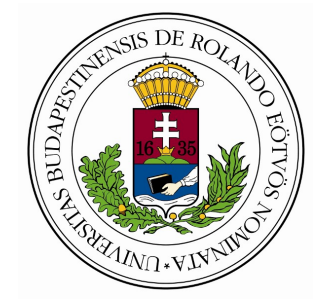

Budapest 2014 
Dissertationes Archaeologicae ex Instituto Archaeologico Universitatis de Rolando Eötvös nominatae

Ser. 3. No. 2.

Editor-in-chief:

DÁvid BARTus

Editorial board:

LÁsZló BARTOSIEWICZ

LÁSZLÓ BORHY

IsTVÁN FELD

GÁBOR KALLA

PÁL RACZKY

MiKLÓs SzABÓ

TIVADAR VIDA

Technical editors:

DÁvid BARTus

GÁBOR VÁCZI

ANDRÁs BÖDŐCS

DÁNIEL SZABÓ

Proofreading:

SZILVIA SzÖLLősI

Available online at http://dissarch.elte.hu Contact: dissarch@btk.elte.hu

$$
\begin{aligned}
& \text { PUBLIC } \\
& \text { KNOWLEDGE } \\
& \text { PROJECT }
\end{aligned}
$$

(c) Eötvös Loránd University, Institute of Archaeological Sciences

Budapest 2014 


\section{Contents}

\section{SElected PAPERS OF THE XI. Hungarian CONFERENCE on Classical Studies}

Ferenc BARNA

Venus mit Waffen. Die Darstellungen und die Rolle der Göttin in der Münzpropaganda

der Zeit der Soldatenkaiser (235-284 n. Chr.)

Dénes GABLER

A belsó vámok szerepe a rajnai és a dunai provinciák importált kerámiaspektrumában

Lajos MATHÉDESZ

Római bélyeges téglák a komáromi Duna Menti Múzeum gyújteményében

Katalin OtTOMÁNYI

Újabb római vicusok Aquincum territoriumán

Eszter SÜVEGH

Hellenistic grotesque terracotta figurines. Problems of iconographical interpretation

András SzABó

Some notes on the rings with sacred inscriptions from Pannonia

István VIDA

The coinage of Flavia Maxima Helena

\section{Articles}

Gábor TARBAY

Late Bronze Age depot from the foothills of the Pilis Mountains

Csilla SÁRó

Roman brooches from Paks-Gyapa - Rosti-puszta

András BöDőcs - Gábor KovÁcs - Krisztián ANDERKó

The impact of the roman agriculture on the territory of Savaria

Lajos JuHÁsz

Two new Roman bronzes with Suebian nodus from Brigetio

\section{FIELD REPORTS}

Zsolt MESTER - Norbert FARAGó - Attila KirÁLy

The first in situ Old Stone Age assemblage from the Rába Valley, Northwestern Hungary

Pál RACZky - Alexandra ANDERs - Norbert FARAgó - Gábor MÁRKus

Short report on the 2014 excavations at Polgár-Csőszhalom 
Preliminary Report on the first season of fieldwork in Berettyóúffalu-Szilhalom

Márton SzILÁgyi - András FüZESI - Attila VIRÁG - Mihály GASPARIK

A Palaeolithic mammoth bone deposit and a Late Copper Age Baden settlement and enclosure

Preliminary report on the rescue excavation at Szurdokpüspöki - Hosszú-dúlö II-III. (M21 site No. 6-7)

Kristóf FüLÖP - Gábor VÁcZI

Preliminary report on the excavation of a new Late Bronze Age cemetery

from fobbágyi (North Hungary)

Lőrinc TimÁr - Zoltán CzAJLik - András BöDőcs - Sándor PuszTA

Geophysical prospection on the Pâture du Couvent (Bibracte, France). The campaign of 2014

Dávid BARtus - László Borhy - Gabriella Delbó - Emese SzÁmadó

Short report on the excavations in the civil town of Brigetio (Szőny-Vásártér) in 2014

Dávid BARTus - László BorHy - Emese SzÁMADó

A new Roman bath in the canabae of Brigetio

Short report on the excavations at the site Szőny-Dunapart in 2014

Dávid BARTus - László Borhy - Zoltán CzAjlik - Balázs Holl -

Sándor PuszTA - László RuPNiK

Topographical research in the canabae of Brigetio in 2014

Zoltán CZAJLIK - Sándor BERECKI - László RUPNIK

Aerial Geoarchaeological Survey in the Valleys of the Mureș and Arieș Rivers (2009-2013)

Maxim MoRDovin

Short report on the excavations in 2014 of the Department of Hungarian Medieval

and Early Modern Archaeology (Eötvös Loránd University, Budapest)

Excavations at Castles Čabrad' and Drégely, and at the Pauline Friary at Sáska

\section{Thesis Abstracts}

Piroska Csengeri

Late groups of the Alföld Linear Pottery culture in north-eastern Hungary

New results of the research in Borsod-Abaúj-Zemplén County

Ádám Bíró

Weapons in the 10-11th century Carpathian Basin

Studies in weapon technology and methodology - rigid bow applications and southern import

swords in the archaeological material

Márta DARÓcZI-SzABó

Animal remains from the mid 12th-13th century (Árpád Period) village of Kána, Hungary

Károly BELÉNYESY

A 15th-16th century cannon foundry workshop in Buda

Craftsmen and technology of cannon moulding and the transformation of military technology

from the Renaissance to the Post Medieval Period 
István RINGER

Manorial and urban manufactories in the 17th century in Sárospatak

\section{BIBLIOGRAPHY}

László BORHY

565

Bibliography of the excavations in Brigetio (1992-2014) 


\title{
The first in situ Old Stone Age assemblage from the Rába Valley, Northwestern Hungary
}

\author{
Zsolt Mester \\ Institute of Archaeological Sciences \\ Eötvös Loránd University \\ mester.zsolt@btk.elte.hu
}

\author{
Norbert FARAgó \\ Institute of Archaeological Sciences \\ Eötvös Loránd University \\ norbert.farago@gmail.com
}

\author{
AtTila KirÁly \\ Institute of Archaeological Sciences \\ Eötvös Loránd University \\ attila@ameplatform.hu
}

\begin{abstract}
Due to the construction of the M86 motorway, intensive quarrying activity started at several locations of the Rába Valley in Northwestern Hungary. This undertaking provided the discovery of a new archaeological site near the village of Páli in August 2014. During the rescue excavation, a rich lithic assemblage was unearthed, suggesting a human occupation related to the Epipalaeolithic-Early Mesolithic period. It is the first in situ site preceding the Neolithic in the region.
\end{abstract}

\section{Introduction}

Due to the construction of the M86 motorway, intensive quarrying activity started at several locations of the Rába Valley. This undertaking provided the discovery of a new archaeological site near the village of Páli in August 2014 which seems to change our view on the Late Pleistocene-Early Holocene population history of the Carpathian Basin. According to our field observations during the rescue excavation of the Páli-Dombok site, we recognised an Epipalaeolithic/Early Mesolithic industry which is the first in situ verified site preceding the Neolithic in Northwestern Transdanubia.

\section{Geographic setting}

The village of Páli is situated in the region named Kisalföld (Little Plain), 60 kilometers Southwest of Győr as the crow flies (Fig. 1). Nowadays, the landscape is defined by the closest rivers, namely the Rába and the Répce. ${ }^{1}$ The general geological stratigraphy of the region consists of fluvial clay, silt and dark brown slope sediment layers at the top, belonging to the Holocene period. Below these, 10 to 50 meters thick gravel and sand layers are lying, deposited by quaternary fluvial activity. During the Late Quaternary, a slow subsidence of the territory contributed to the accumulation of these sediments. The Páli-Dombok site is located five kilometers south from the village, where a sand pit was exploited by the locals since a long time (Fig. 2). The M86 Motorway construction developed further economic interest in gravel extraction here. At the old spot, a new pit has been initiated in August 2014.

1 DöVÉNYI 2010, 310. 


\section{The discovery and the rescue excavation of the site}

Páli-Dombok was already registered as an archaeological site because remains of a settlement from the Roman period were found on the surface next to the old sand pit of the village. Some Prehistoric (probably Neolithic) pits with very poor archaeological material were also reported during the archaeological survey before the opening of the new gravel pit.

On the 28th of August 2014, János Hatos archaeologist assistant found five knapped stone artifacts in the sediments of the southern slope of the gravel pit at approximately two metres under the actual surface. According to his observations, the lithics came from a loamy sediment deposited directly on the thick gravel layer. Máte Losonczi archaeological inspector at the county has stopped the exploitation and contacted us at the Institute of Archaeological Sciences of the Eötvös Loránd University. Unfortunately, the verification of the stratigraphic context of the artifacts was no more possible during our visit at the site on the 12th of September. On the 3rd of October, Janos Hatos found two blades and a core fragment, made of radiolarite, in the slope a dozen meters further to the west from the location of the first discovery. This time the quarrying has stopped immediately. This way we could carry out a test excavation for verifying the stratigraphic context on the 10th of October. Seventeen lithic artifacts have been recorded on an excavated area of one and a half square meters. They were unearthed from the dark grey palaeosoil-like sediment overlaying the lowermost loamy layer above the gravels. The positions of the finds suggested the existence of an archaeological horizon (Fig. 3).

Taking into account that the archaeological material consists of debitage products, including very small flakes - probably from retouching tools - and some core fragments, in an undisturbed stratigraphic position, a conclusion was drawn that we are facing the remains of human occupation. Although the lithics were undiagnostic from a taxonomic point of view, their position at the bottom of the sequence of the sediments over the gravel allows to suppose quite an old age. On the geological map of Hungary, the area concerned is marked as a fluvial sand and gravel formation of Middle-Upper Pleistocene age (Qp4). ${ }^{2}$ Based on these results, a rescue excavation was necessary which has been carried out between the 30th of October and the 7th of November (Fig. 4).

The $4 \times 1 \mathrm{~m}$ trench was thoroughly excavated by hand tools in very thin layers. By this method we could record the original location of all the finds, even chips less than $5 \mathrm{~mm}$ of diameter. The locations were registered by $x y z$ coordinates, enabling us to take further spatial analyses in a georeferred system. Altogether 925 artifacts were secured during the excavation. They are exclusively knapped stones: retouched tools, flakes, retouch flakes, blades, bladelets, rejuvenation removals, and cores. According to our field observations, they came from a well defined archaeological level of 5-6 cm thickness which belongs to the lower part of the palaeosoil-like sediment layer (Fig. 5).

\section{The knapped stone assemblage}

The raw material of the lithic collection is very homogenous, all 925 pieces belong to the radiolarite types coming from the Jurrasic formations of the Bakony Mountains. ${ }^{3}$ The assemblage

2 Budai - Gyalog 2009, 52.

3 Biró - Dobosi 1991; Biró 2008. 
is abundant in light brown, sometimes striped variations, however dark brown pieces occur also. The maximum length of the artifacts varies between 2-3 $\mathrm{mm}$ to $60-70 \mathrm{~mm}$. More than 50 percent of the knapped stones falls below $5 \mathrm{~mm}$ in size, testifying in situ tool production. Although the complete technological evaluation is still pending, the chaîne opératoire seems fairly complete at the site. Blanks of all sizes and types are present, core preparing and rejuvenating flakes, core tablets, cortical pieces, complete blades and bladelets are very frequent (Fig. 6). The scarcity of cores awaits explanation, only half a dozen were present. They are quite exhausted, but the signs of blade debitage are apparent. Retouched tools are not numerous either, at this point of the examination only a dozen can be mentioned. Among them several end scrapers, a bifacially formed piece, a triangle, a backed point, a truncated blade and a burin are worth to mention (Fig. 7). The presence of microlithic elements and the overall character of the tools allow us to locate the Páli assemblage in the Epipalaeolithic-Early Mesolithic cultural era.

\section{The spatial interpretation}

The high number of very small removals was already salient during the fieldwork. Three size categories were created for the findings in order to investigate their spatial distribution. Kernel density maps were generated with a radius of seven on the horizontal distribution of the artifacts using $x y$ coordinates. Having a look on the three density maps (Fig. 8) it becomes clear that the three size categories have different weight points. This size-related variability can be interpreted as sign of discrete spatio-temporal stages of stone tool production. One of the key topics in intra-site analysis is the question of dense find concentrations. Two possible answers for such arrangements are dumping and knapping. ${ }^{4}$ Danish experimental archaeologists, replicating the flint knapping method of the Mesolithic Kongemose culture, showed that the two types of find accumulation create statistically different patterns. In case of dumping, the composition is more homogenous in size, than in a knapped stone concentration. ${ }^{5}$

\section{The Epipaleolithic/Mesolithic in Transdanubia and the beginning of the Neolithic}

The significance of the new site at Páli can be evaluated in context of the problem of the Epipalaeolithic-Mesolithic period in Hungary. This period is underrepresented in the Hungarian prehistoric research, however such sites occur in the scientific literature since the 1930s. ${ }^{6}$ Most of them are stray finds coming from surface surveys, like the bone harpoons from the environs of Csór, ${ }^{7}$ the enigmatic assemblages from the region of Győr, ${ }^{8}$ or the Mesolithic/Neolithic sites in the Vázsony Basin. ${ }^{9}$ Two further assemblages from Kaposhomok and Pamuk were subjects of a more recent revision by Tibor Marton, who excluded the later site from the Mesolithic period. ${ }^{10}$ Only three sites were excavated from this chronological horizon along the Danube and in Transdanubia. Sződliget-Vác ${ }^{11}$ and Szekszárd-Palánk ${ }^{12}$ were investigated in the middle of the last century, since then they did not go through a complex

\footnotetext{
4 JOHANSEN - STAPERT 1998, 29.

5 JOHANSEN - STAPERT 1998, 31.

6 VÉrtes 1965, 212-222; Dobosi 1975, 68-70.

7 Marosi 1936; MAKKAY 1970.

8 Gallus 1942.

9 MÉSZÁros 1948; Biró 1992.

10 MARTON 2003.

11 GÁBORI 1956; 1968.

12 VÉRTES 1962.
} 
revision despite the many questions and problems arising around them. Concerning Sződliget-Vác, a reevaluation of the assemblage was made in the frame of an unpublished MA thesis by Dávid Kraus, ${ }^{13}$ while for the assemblage of Szekszárd-Palánk only the raw material use was treated in a paper by Róbert Kertész and Orsolya Demeter. ${ }^{14}$ The site of Regöly 2 was examined more recently by a team leaded by William J. Eichmann, but the fully conducted evaluation is still in progress. ${ }^{15}$ On the occasion of this later assemblage the authors concerned the question of the emergence of the first farming communities in North-Transdanubia.

The relationship between indigenous (Mesolithic) and immigrant (Neolithic) populations constitutes a paramount scientific problem concerning this period as a whole. One aspect of this riddle is the adoption of agriculture by Mesolithic peoples from the freshly settled bearers of the Starčevo culture, the first food-producing populations in the region. Was there any cultural contact of this kind or not? More importantly, is there any sign of an indigenous population through the times, which was substantial enough to build models of contact on it? From this point of view it is crucial to investigate the Epipalaeolithic, Mesolithic and Early Neolithic periods in more detail, because the formation of the LBK is connected to this region since a long time. ${ }^{16}$ Obviously this problem can be approached the most easily by the omnipresent knapped stone industries in these periods, but until now we did not dispose stratified sites on the territory of Northwestern Transdanubia. At this point some of the scholars are very cautious to see continuity between the Mesolithic and the Neolithic, ${ }^{17}$ some of them rather neglect any connection between these periods ${ }^{18}$ and some of them suppose a clear similarity between the two knapped stone industries. ${ }^{19}$

\section{Acknowledgements}

Máté Losonczi, archaeological inspector at the Government Office for Győr-Moson-Sopron County recognized immediately the importance of the first finds and made one's utmost to save the site. We are grateful to him for it and for all his help during the rescue excavation. We are indebted to János Hatos archaeologist assistant from the Rómer Flóris Museum in Győr for discovering the knapping stone artifacts and for sharing the precious informations coming from his field surveys. The excavation would be impossible without the help and support of the EKS-Gránit Ltd. and especially of József Surányi managing director. We thank also the colleagues from Rómer Flóris Museum in Győr and the staff of the mine for technical help. Last but not least, we are grateful to Éva Halbrucker and Attila Péntek, members of the excavation team, for their enthusiasm and assiduousness. Without their keen eyes the outstanding results of the excavation would not be possible.

\footnotetext{
13 Kraus 2011.

14 Kertész - Demeter 2011. Re-evaluation of the Szekszárd-Palánk assemblage is now underway by Róbert Kertész, Orsolya Demeter and Attila Király.

15 Eichmann 2004; BÁNfFy ET AL. 2007; Eichmann ET AL. 2010.

16 QUiTTA 1960.

17 Biró 1987, 165; BÁcskay 1976, 101; Biró 2002, 129; Biró 2007, 73.

18 Kaczanowska 2001; KozŁowski 2001; Kaczanowska - KozŁowski 2014.

19 Mateiciucová 2004; Eichmann ET AL. 2010.
} 


\section{References}

BÁcskAy, E. 1976: Early Neolithic chipped stone implements in Hungary. Dissertationes Archaeologicae Ser. II. No. 4. Budapest.

BÁnffy, E. - Eichmann, W. J. - Marton, T. 2007: Mesolithic foragers and the spread of agriculture in Western Hungary. In: KozŁowski, J. K. - Nowak, M. (eds): Mesolithic/Neolithic interactions in the Balkans and in the Middle Danube Basin. British Archaeological Reports, International Series 1726. Oxford, 53-62.

Bıró, K. T. 1987: Chipped stone industry of the Linearband Pottery Culture in Hungary. Archaeologia Interregionalis 240, 131-167.

BıRó, K. T. 1992: Mencshely-Murvagödrök kőanyaga-Steinartefakte aus neue Grabungen von Mencshely. Tapolcai Városi Múzeum Közleményei 2, 51-72.

Biró, K. T. 2002: Advances in the study of Early Neolithic lithic materials in Hungary. Antaeus 25, 119-168.

BIRó, K. T. 2007: Early Neolithic raw material economies in the Carpathian Basin. In: KozŁowski, J. K., - NowaK, M. (eds.): Mesolithic/neolithic Interactions in the Balkans and in the Middle Danube Basin. British Archaeological Reports, International Series 1726. Oxford, 63-75.

BıRó, K. T. 2008. Kőeszköz-nyersanyagok Magyarország területén. A Miskolci Egyetem Közleménye A sorozat, Bányászat 74, 11-37.

Biró, K. T. - Dobosi, V. T. 1991: Litotheca - Comparative Raw Material Collection of the Hungarian National Museum. Budapest.

Budai, T. - Gyalog, L. (ed.) 2009: Magyarország földtani atlasza országjáróknak - 1:200 000 - Geological Map of Hungary for Tourists. Budapest.

Doвоsı, V. T. 1975: Magyarország ős- és középsőkőkori lelőhely katasztere (Register of Palaeolithic and Mesolithic sites in Hungary). Archaeologiai Értesitő 102, 64-76.

DövÉNYI, Z. (ed.) 2010: Magyarország kistájainak katasztere. Budapest.

EIchmanN, W. J. 2004: Mesolithic hunter-gatherers in the Carpathian Basin and the spread of agriculture in Europe. In: Huszár, I. (ed.): Fulbright Student Conference Papers. Budapest, 161-202.

Eichmann, W. J. - Kertész, R. - Marton, T. 2010: Mesolithic in the heartland of Transdanubia, Western Hungary. In: Gronenborn, D. - Petrasch, J. (eds.): Die Neolithisierung Mitteleuropas - The spread of the Neolithic. RGZM Tagungen Band 4, Mainz, 211-233.

Gallus, S. 1942: Győr története a kőkortól a bronzkorig. In: Gallus S. - Mithay S.: Győr története a vaskorszakig. Győr, 7-79.

GÁBori, M. 1956: Mezolitikus leletek Sződligetről (Mesolitische Funde von Sződliget). Archaeologiai Értesitő 83, 177-182.

GÁBORI, M. 1968: Mesolithische Zeltgrundriss in Sződliget. Acta Archaeologica Academiae Scientiarum Hungaricae 20, 33-36.

Johansen, L. - StApert, D. 1998: Dense flint scatters: Knapping or dumping? In: Conard, N. J. KInD, C.-J. (ed.): Aktuelle Forschungen zum Mesolithikum - Current Mesolithic Research. Urgeschichliche Materialhefte 12. Tübingen. 
Kaczanowska, M. 2001: Feuersteinindustrie des westlichen und östlichen Kreises der Linearbandkeramikkultur - ein Vergleichsversuch. In: Kertész, R. - Makkay, J. (eds.): From the Mesolithic to Neolithic. Szolnok, 215-223.

Kertész, R. - Demeter, O. 2011: Adatok a dunántúli kora mezolitikum kőiparának nyersanyagvizsgálatához: Szekszárd-Palánk (Contributions to raw material studies of the Transdanubian Early Mesolithic lithic industry: Szekszárd-Palánk). In: Bıró, K. T. - Markó, A. (eds.): Emlékkönyv Violának. Tanulmányok T. Dobosi Viola tiszteletére. Papers in honour of Viola T. Dobosi. Budapest, 113-128. http://mek.oszk.hu/09 200/09253/pdf/kertesz.pdf

KozŁowski, J. K. 2001: Evolution of lithic industries of the Eastern Linear Pottery Culture. In: Kertész, R. - Makkay, J. (eds.): From the Mesolithic to the Neolithic. Szolnok, 247-260.

Kaczanowska, M. - KozŁowski, J. K. 2014: The origin and spread of the Western Linear Pottery Culture: between forager and food producing lifeways in Central Europe. Archaeologiai Értesitó 139, 293-318.

Kraus, D. 2011. Duna környéki epipaleolit és mezolit leletanyagok. Unpublished MA-thesis. Budapest.

MakкAy, J. 1970: A kőkor és rézkor Fejér megyében. In: Fitz, J. (ed.): Fejér megye története 1. Fejér megye története az őskortól a honfoglalásig. Székesfehérvár.

Marosi, A. 1936: A székesfehérvári múzeum csontszigonya. Archaeologiai Értesítő 49, 83-85.

Marton, T. 2003: Mezolitikum a Dél-Dunántúlon - A somogyi leletek újraértékelése. Móra Ferenc Múzeum Évkönyve - Studia Archaeologica 9, 39-48.

Mateiciucová, I. 2004: Mesolithic tradition and the origin of the Linear Pottery Culture (LBK). In: Lukes, A. - Zvelebil, M. (eds.): LBK Dialogues. Studies in the formation of the Linear Pottery Culture. British Archaeological Reports, International Series 1304, Oxford, 91-107.

MÉszÁRos, Gy. 1948: A vázsonyi medence mezolit- és neolitkori települései. Veszprém.

Quitta, H. 1960: Zur Frage der ältesten Bandkeramik in Mitteleuropa. Prähistorische Zeitschrift 38, 153-188.

VÉRTES, L. 1962: Die Ausgrabungen in Szekszárd-Palánk und die archäologischen Funde. wiatowit 24, 159-202.

VÉRTES, L. 1965: Az őskőkor és az átmeneti kőkor emlékei Magyarországon. A Magyar Régészet Kézikönyve 1, Budapest. 


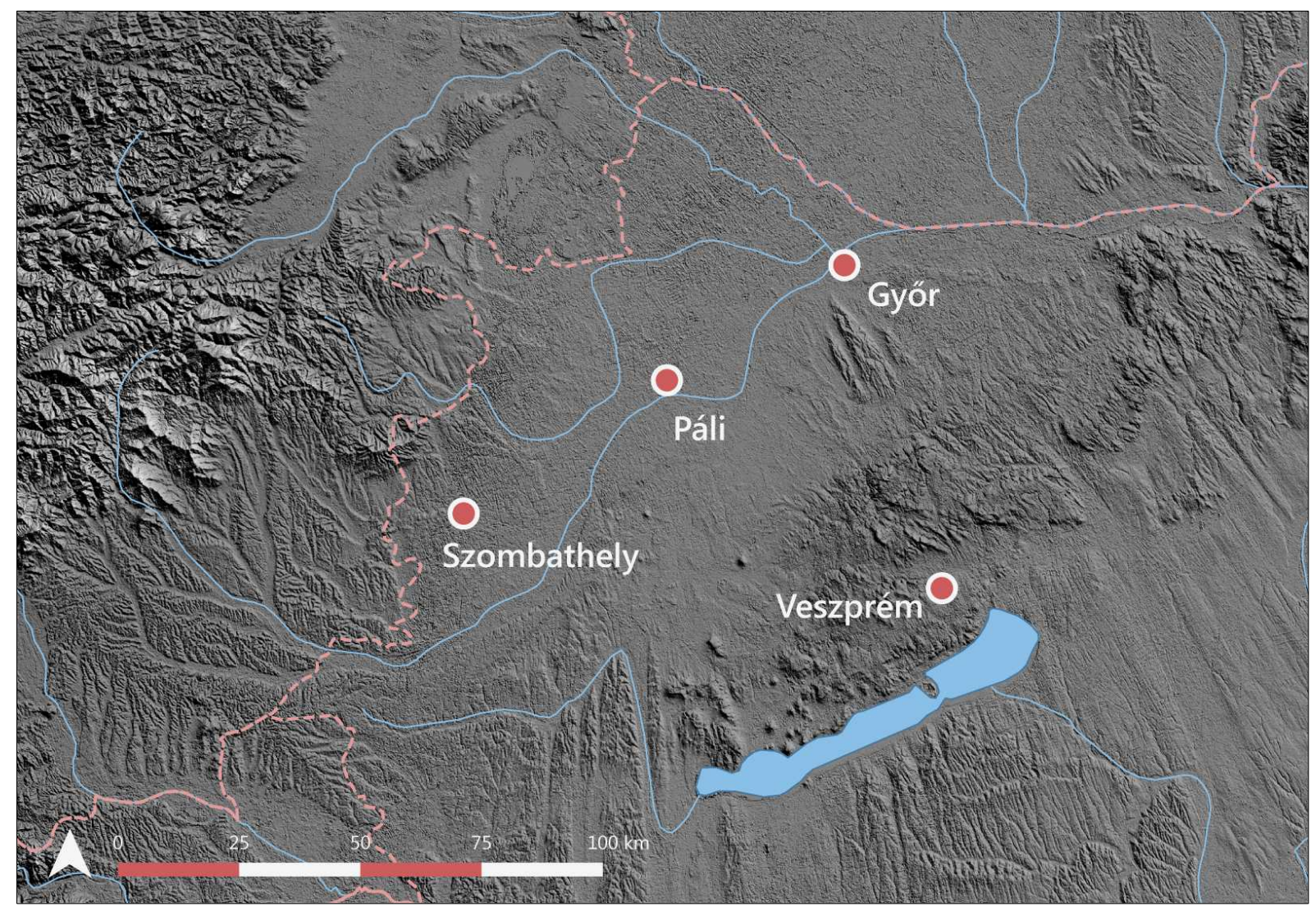

Fig. 1. Location of the village Páli in Northwestern Hungary.

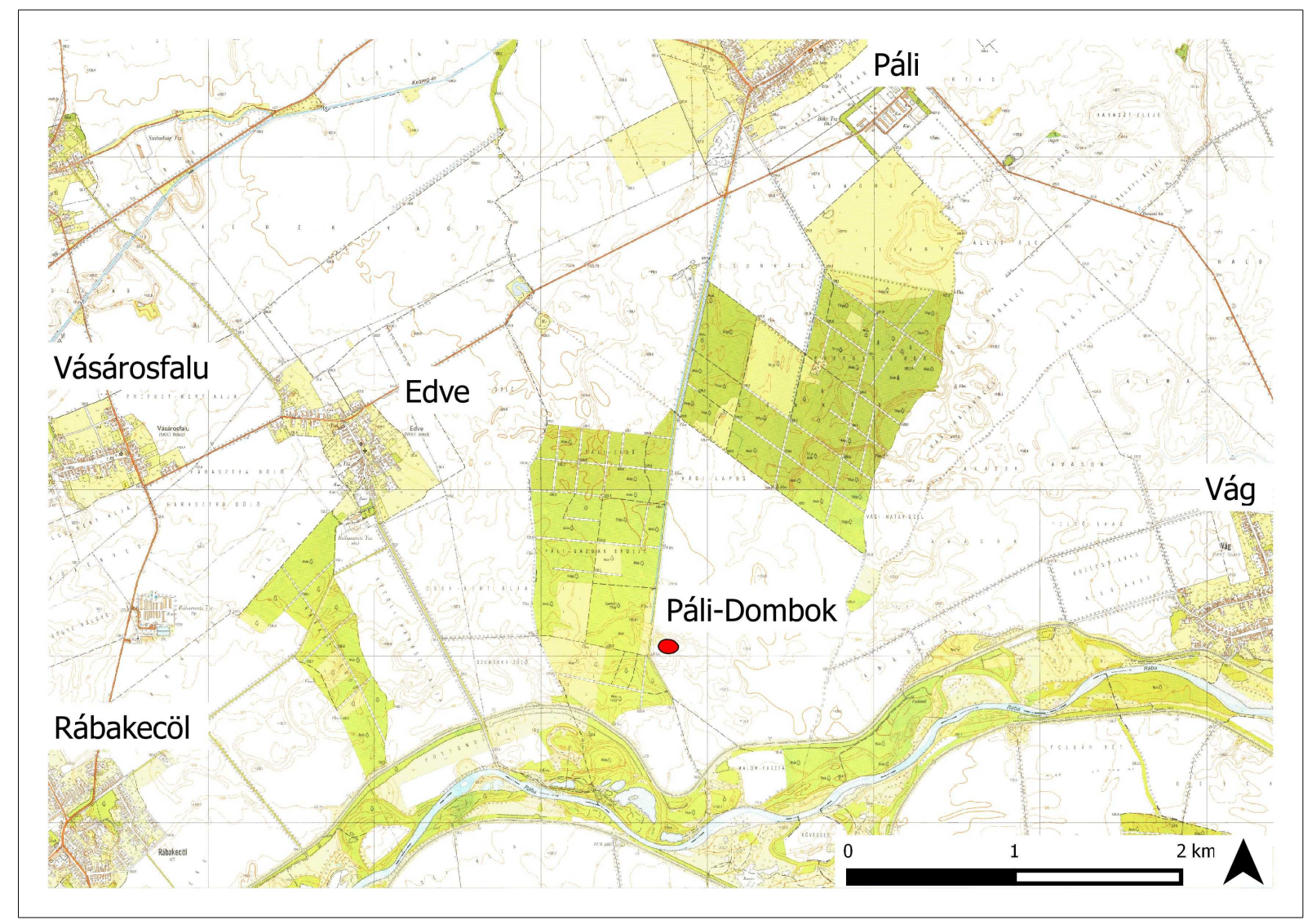

Fig. 2. Location of the Páli-Dombok site. 


\section{Zs. Mester - N. Faragó - A. KirÁly: The first in situ Old Stone Age assemblage from the Rába Valley}

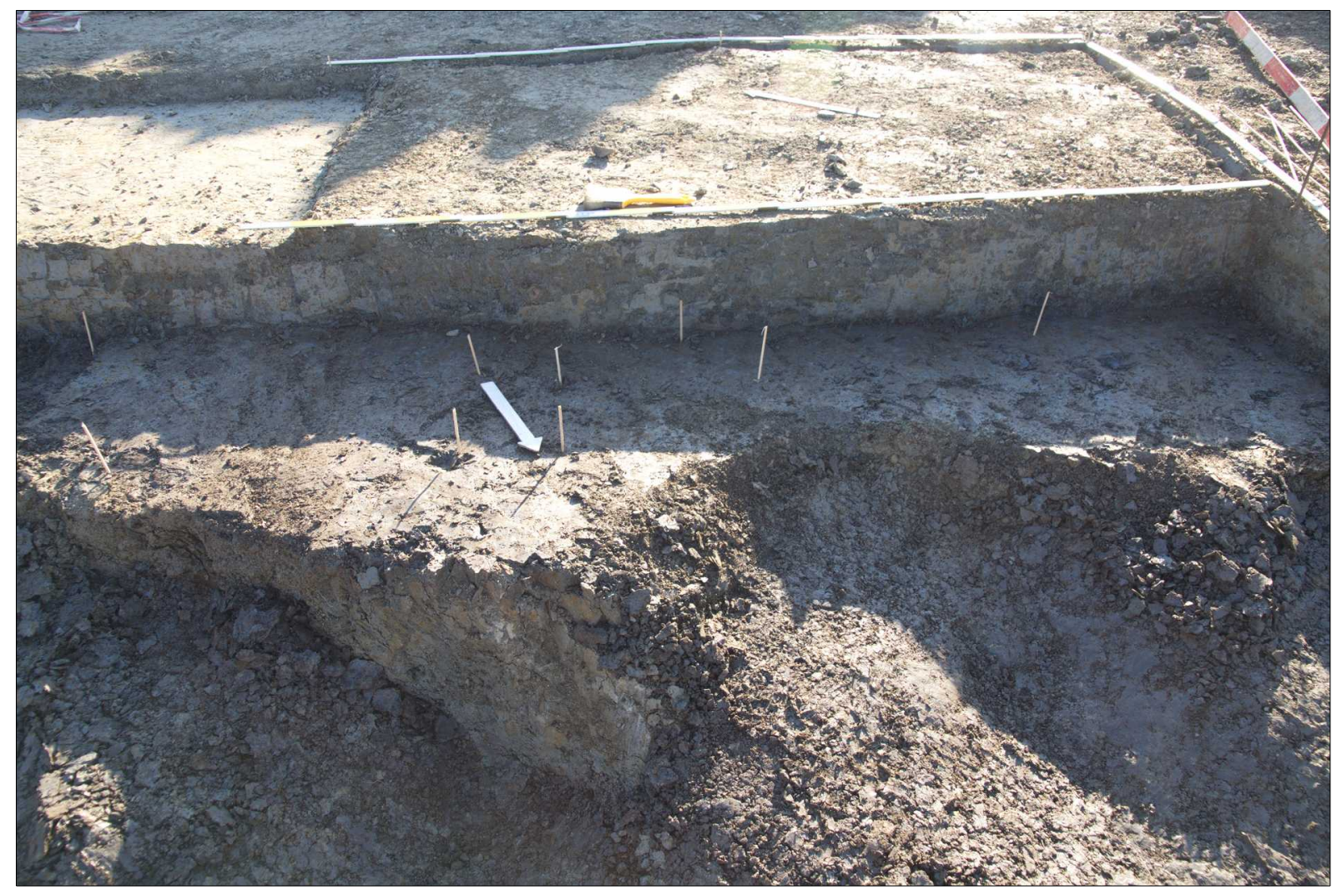

Fig. 3. Test excavation of the site. Note the horizontal arrangement of the artifacts marked by sticks. (Photo: N. Faragó).

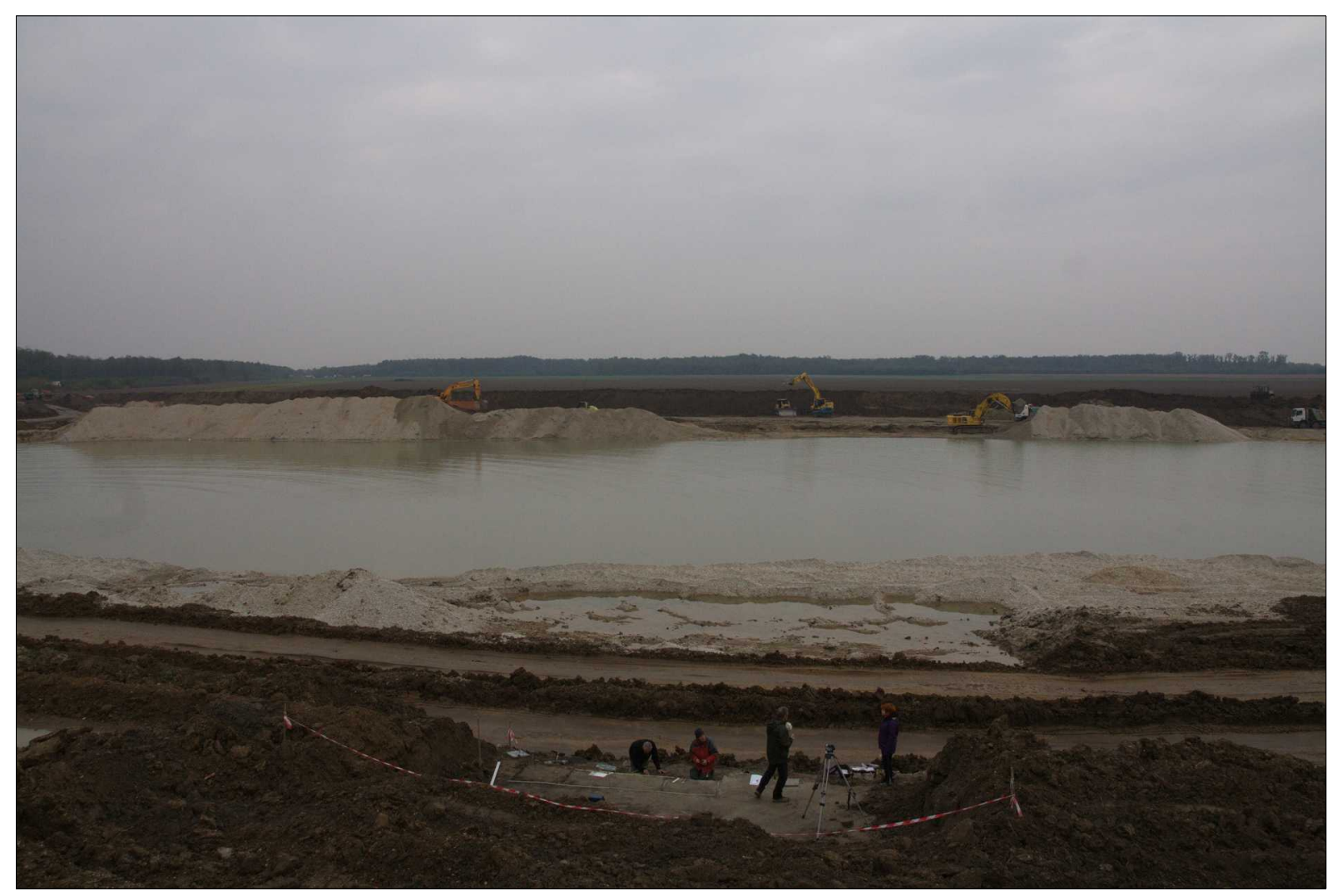

Fig. 4. View of the site during the rescue excavation. (Photo: N. Faragó). 


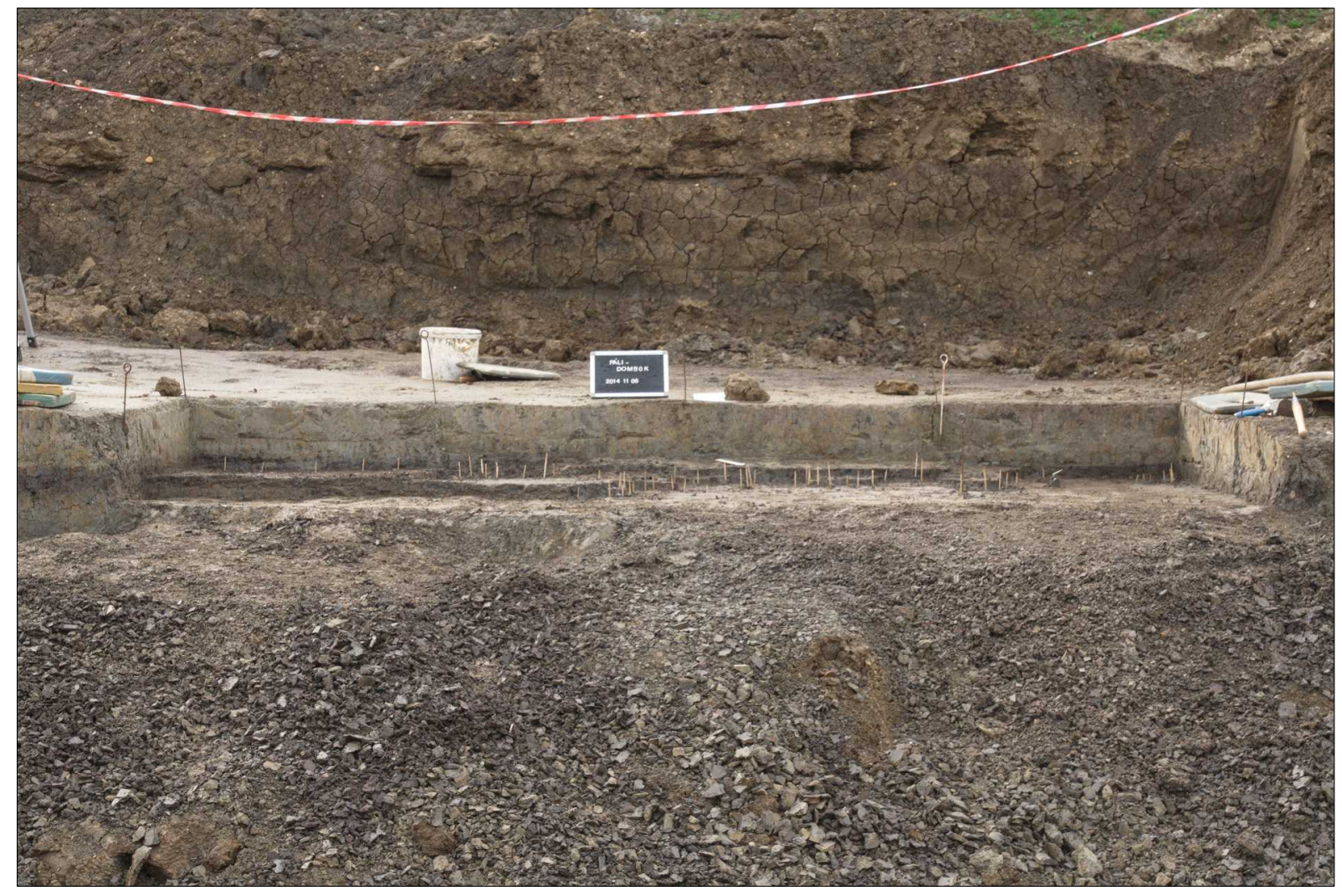

Fig. 5. View of the trench during excavation, showing the stratigraphic position of the archaeological level. (Photo: N. Faragó). 


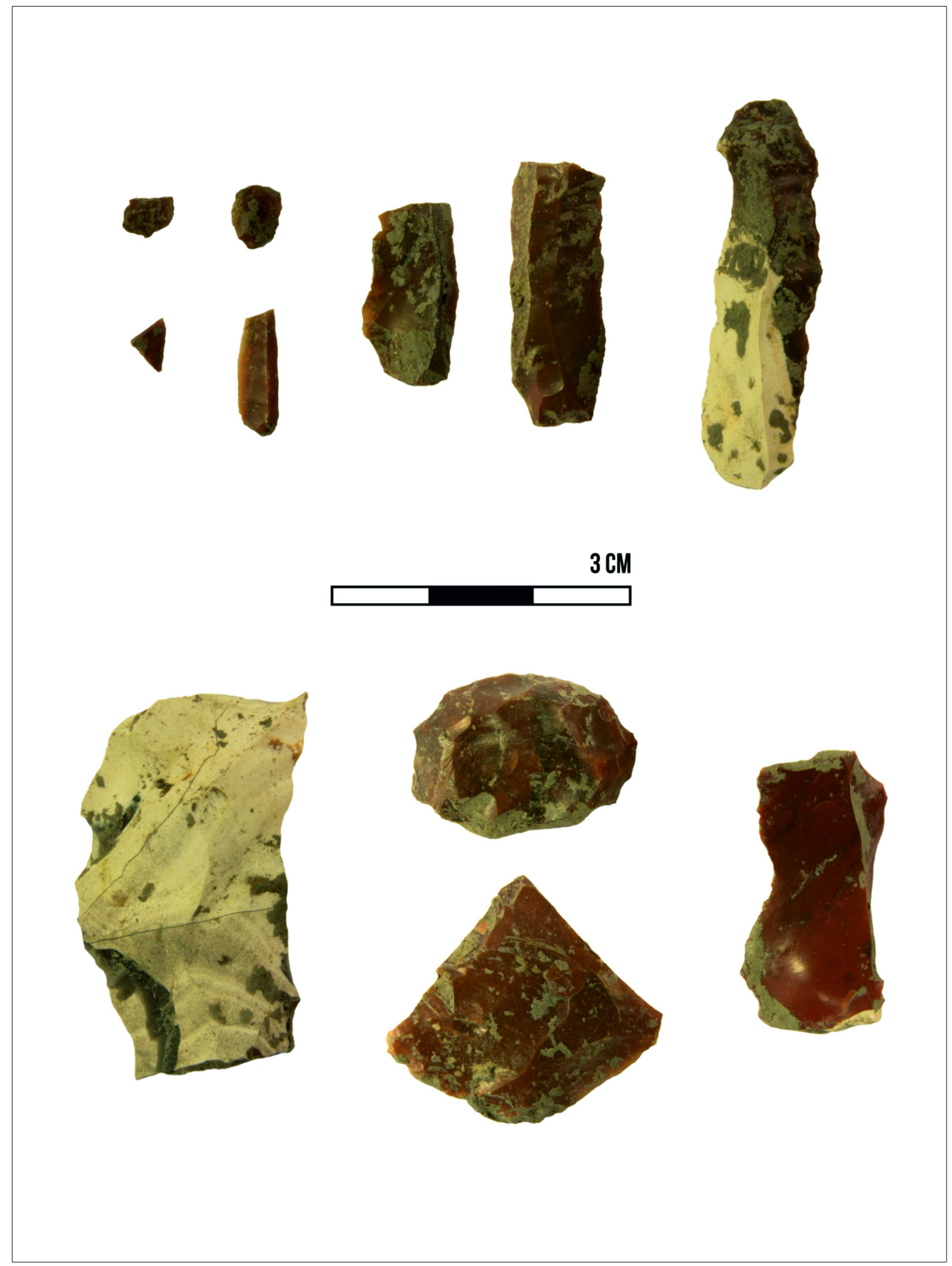

Fig. 6. Selected pieces demonstrating the overall character of the lithic assemblage. (Photo: N. Faragó; design: A. Király). 

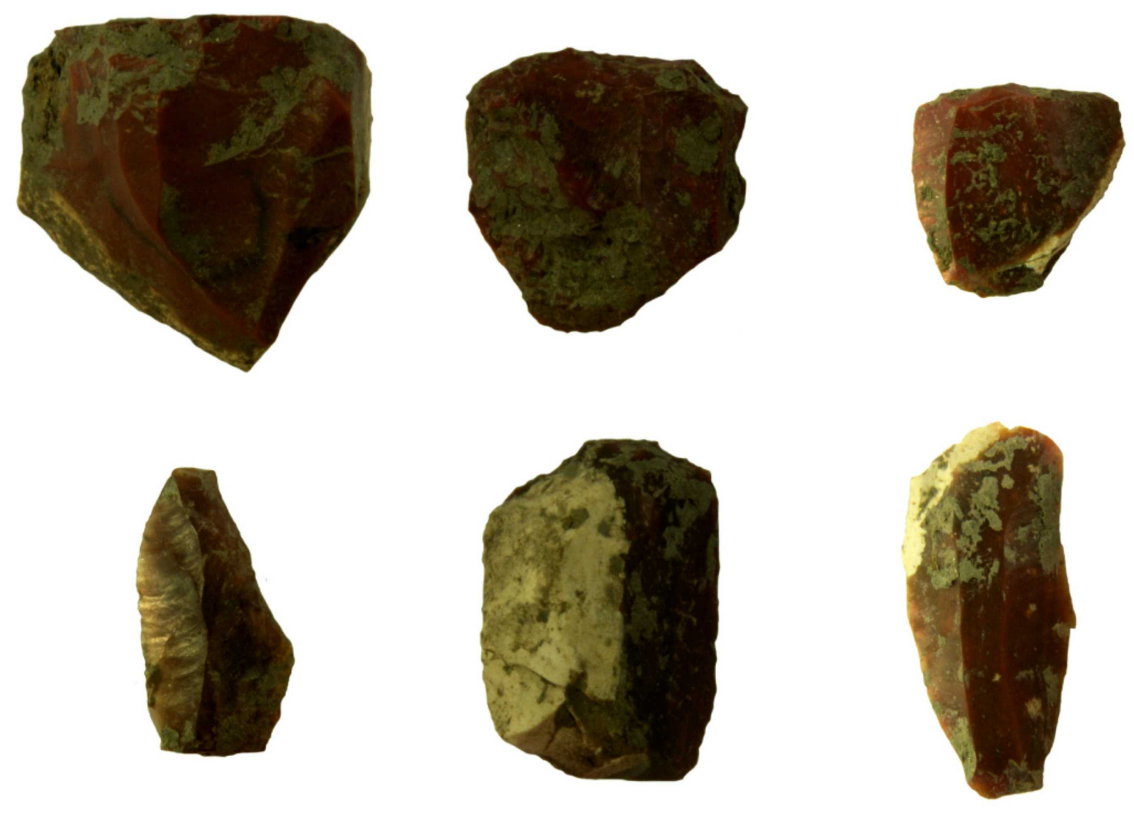

$3 \mathrm{CM}$
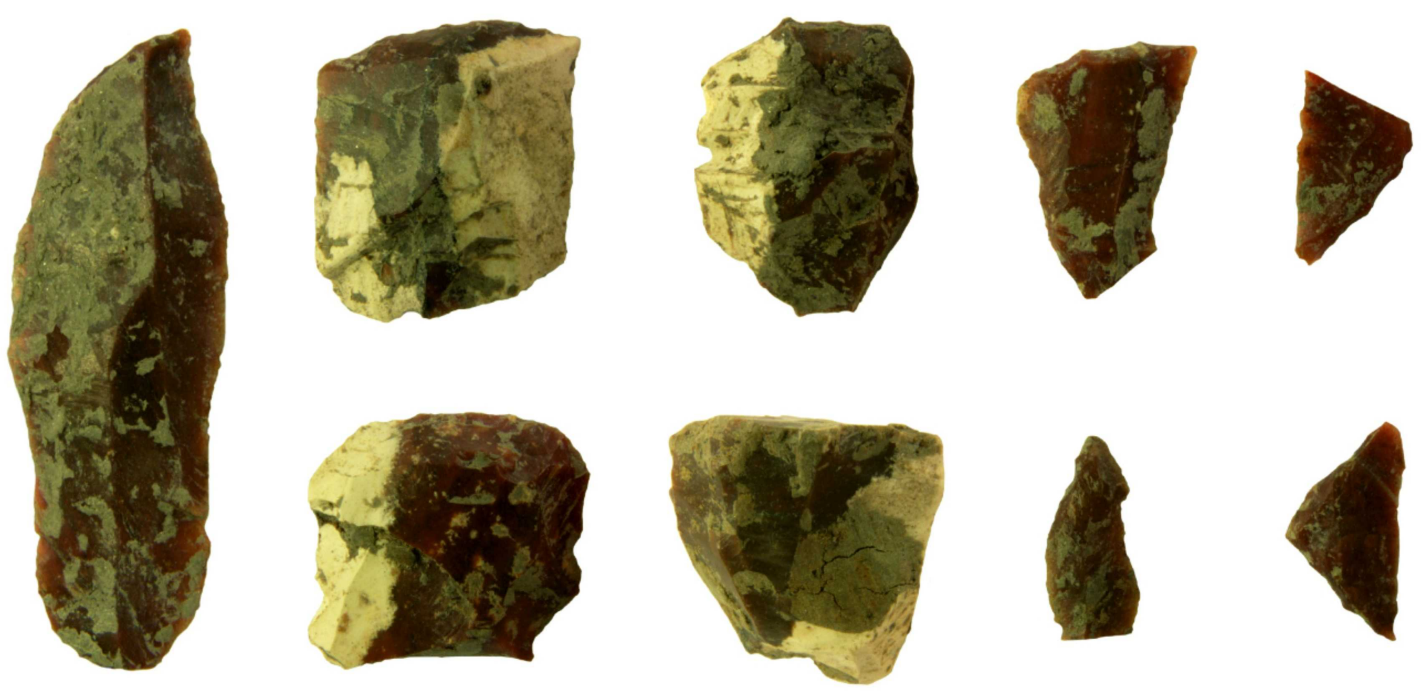

Fig. 7. Retouched tools from the lithic assemblage. (Photo: N. Faragó; design: A. Király). 


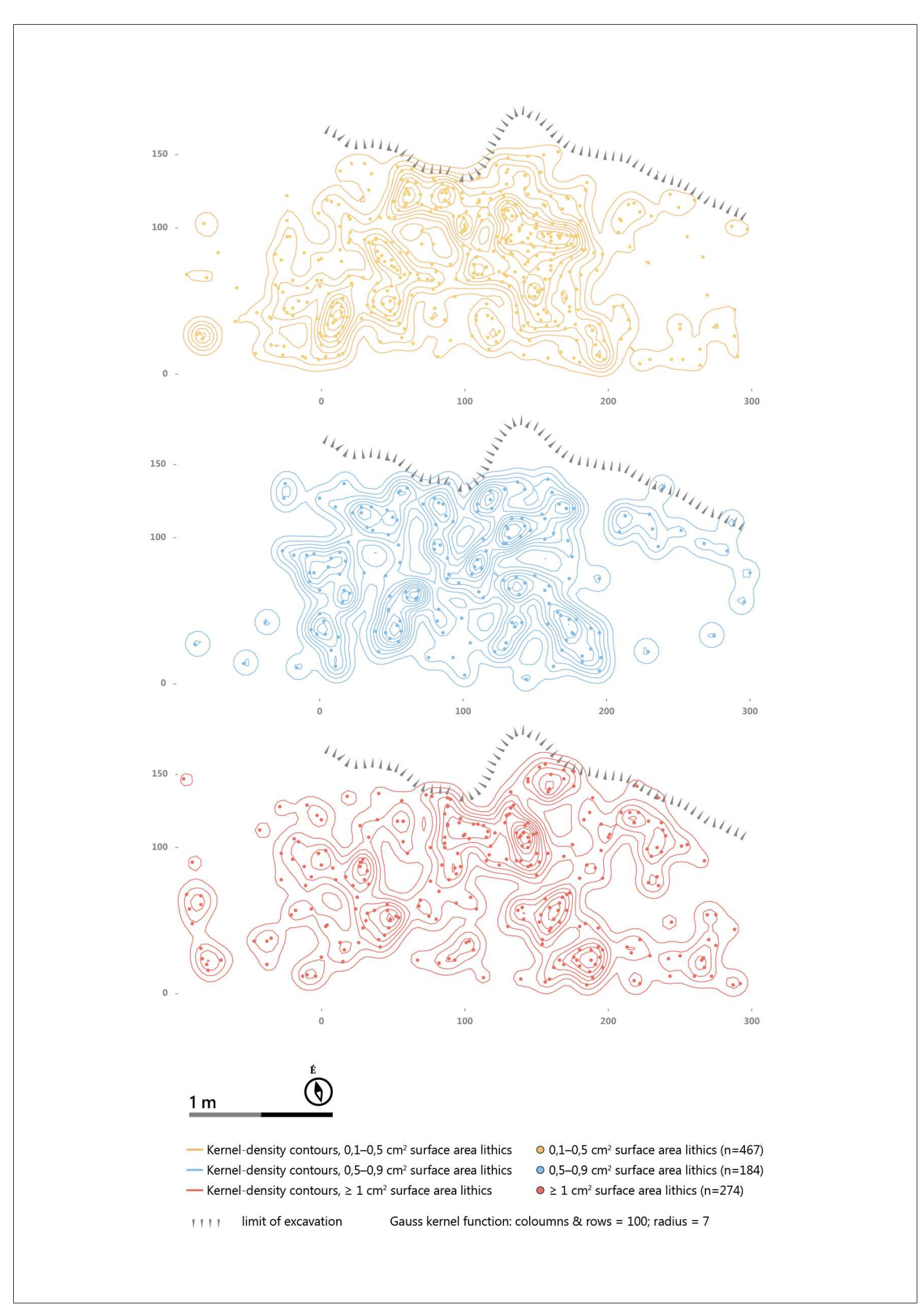

Fig. 8. Kernel density map of the horizontal distribution of the artifacts. (Design: A. Király). 